\title{
Surface Characterization of Oleic Acid Coated Marble Dust
}

\author{
Ercan POLAT ${ }^{1^{*}}$, Taki GÜLER ${ }^{1)}$, Oktay CELEP'), Selçuk AKTÜRK ${ }^{3)}$
}

\footnotetext{
${ }^{1)}$ Muğla Sıtkı Koçman University, Mining Engineering Department

2) Karadeniz Technical University, Mining Engineering Department

${ }^{3)}$ Muğla Sıtkı Koçman University, Department of Physics

${ }^{\star}$ Corresponding author: epolat@mu.edu.tr
}

http://doi.org/10.29227/IM-2020-01-20

Submission date: 24-04-2019 | Review date: 08-05-2019

\begin{abstract}
Calcite, being the most abundant mineral on earth crust, have wide application areas especially in polymer industry as a micronized functional filler material. It is hydrophilic in natural form, and made hydrophobic after surface modification to meet the requirements of polymer industry: the incompatibility between high energetic hydrophilic surface of calcite and the low-energy surface of hydrophobic polymers is a major problem. Treatment of micronized calcite with fatty acids is one of the most common method to obtain modified mineral surface. In present study, oleic acid (OA), fatty acid type surface modifying agent was used for the surface characterization of $O A$ coated marble dust. Fine tailings of slab cutting unit of a marble processing plant was supplied. The sample was subjected to wet classification process to obtain micronized calcite fraction for experimental works. Surface modification of finely sized fraction was performed in a laboratory type flotation unit. Thermogravimetric analysis (TGA) and Transmission Electron Microscopy (TEM) were used as characterization techniques.
\end{abstract}

Keywords: surface modification, oleic acid, marble waste, micronized calcite

\section{Introduction}

Natural stone powders find many industrial applications as raw material, such as in the production of ceramics, bricks, cement and polymer based composite materials. Calcite $\left(\mathrm{CaCO}_{3}\right)$ is one of the most abundant source of natural stone powders. It is preferred in many application areas due mainly to lower cost of production and its appreciable physical properties. Its powder has been used as functional filler.

Huge amount of fine calcite powder is produced during slab cutting in marble processing plants. Majority of the marble dust is not consumed, and rejected to ponds as fine tailings. Considerable amount of stocked dust causes several environmental problems like increasing alkalinity of soil and ground/underground water, decrease in the permability of surface soil, and adverse effect on the flora and fauna.

Grinding cost constitute the major item in the production of ground calcium carbonate (GCC) as a filler material. From this scope of view, marble dust has a reasonable potential to be utilised as GCC due to its size distribution in present form. Surface treatment of GCC is the key process in the polymer industry. Hydrophobic surface is required for perfect suspension of GCC as filling material in polymer phase. Since, in the natural form, surface tensions of calcite and hydrophobic polymers considerable differ from each other which inhibit perfect distribution of GCC in the composite phase (Fan et al., 2015; Hao et al., 2007; Mihajlovic et al., 2009; Shen et al., 2009; Zhang et al., 2010).

Surface of GCC is generally modified by fatty acids. Commonly used modifying agent is stearic acid. Due to high melting temperature of this fatty acid, surface coating of GCC is achieved above $70^{\circ} \mathrm{C}$. On the other hand, oleic acid (OA), as a promising alternative of coating agent, presents in liq- uid phase at ambient temperature. Then, it does not require thermal treatment during coating process. OA, long chain surfactant, has been used as a surface modifier by creating organophilic layer on the mineral surface to improve the dispersibility (Osman and Suter, 2002; Zullig and Morse, 1988). The OA dosage used in the coating process is both technical and economical issue in filler industry in the view of quality of the production. The required optimum modification on mineral surface may be adversely effected in the case of both lower and excessive consumption (Ahsan and Taylor, 1998; Fekete, 1990) due to insufficient coating and multilayer formation, respectively.

Most widely used surface treatment methods are broadly classified into three: chemical, physical and mechano-chemical. Calcite is blended with the modifying agent by a mixer as a dry process at temperature above $70^{\circ} \mathrm{C}$, while the wet method usually includes treatment of calcium carbonate with a solution of the surface modifier in a non-polar solvent. The product with a lower quality in dry processes may be obtained due to poor stirring, low mixing degree, unsufficient dispersion of the modified mineral and uncompleted reactions during coating process present in the case of conventional methods (Hao et al., 2007; Mihajlovic et al., 2009; Osman and Suter, 2002). On the other hand, coating in the presence of non-polar solvent might not be beneficial due to increased cost of process. Then, floating of hydrophobized particles in a flotation system was thought to be promising alternative for calcite coating. In the present study, OA treatment of fine calcite tailings of slab cutting units of a marble processing plant was investigated by flotation method. Thermogravimetric analysis (TGA) and Transmission Electron Microscopy (TEM) were the tools for surface characterization of coated product. 


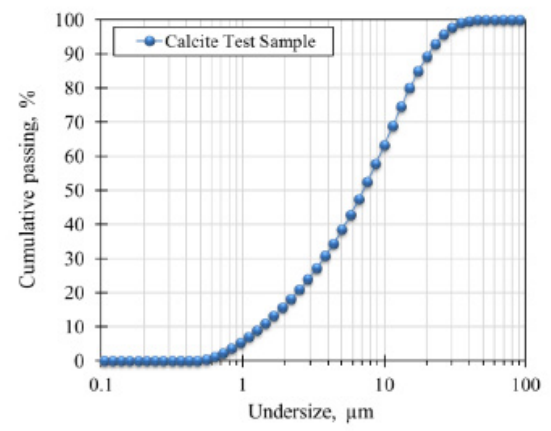

Fig. 1. Particle size distribution of test sample Rys. 1. Skład ziarnowy badanej próbki

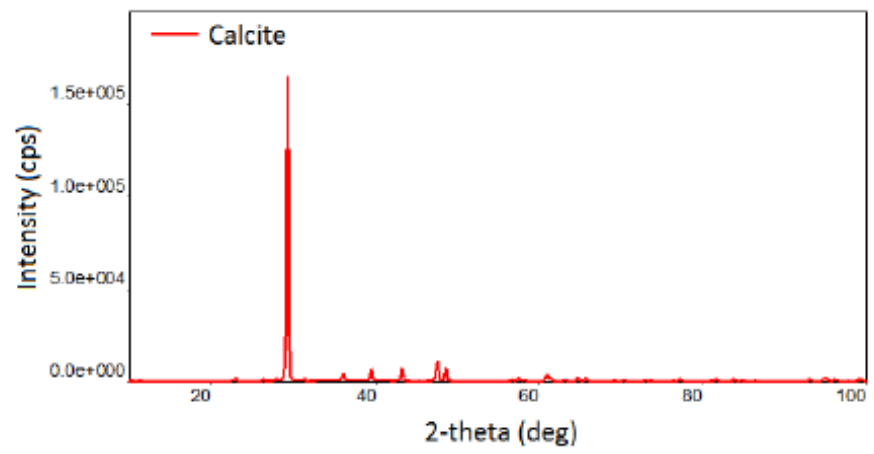

Fig. 2. XRD results of the test sample Rys. 2. Wyniki XRD badanej próbki

\section{Materials and methods}

The representative cutting slurry was obtained from a marble stone slab cutting unit of a marble processing plant in Bayır/Muğla, Turkey. Supplied sample having a size of -106 $\mu \mathrm{m}$ (Figure 1) was first subjected to wet classification process to obtain micronized calcite fraction as a test sample for surface modification experimental works. Particle size distribution of the test sample was performed by laser particle analyzer (Malvern Mastersizer $2000 \mathrm{MU}$ ). Most of the calcite particles in the test sample ( $>90 \%)$ was below than $20 \mu \mathrm{m}$. Mineralogical characterization of sample was performed by X-ray powder diffraction (XRD) method by SmartLab Rikagu XRD instrument. XRD pattern of test sample was given in Figure 2. Obtained XRD pattern with about $0.5 \%$ presicion revealed that main constituting mineralogical phase of test sample was calcite.

Calcite modification tests were performed by Denver flotation unit in a $2 \mathrm{~L}$ flotation cell. Amount of test sample used in each experiment was $145 \mathrm{~g}$. Analytical grade OA supplied by MERCK was used as coating agent at different concentrations $(0,1,3.5,10,25 \mathrm{~kg} / \mathrm{t})$. Conditioning of OA was applied for $8 \mathrm{~min}$. Frother $(100 \mathrm{~g} / \mathrm{t}$ MIBC) was used to obtain stable froth in all tests. The stirring speed was adjusted to $1300 \mathrm{rpm}$ both during conditioning and froth skimming stages. The coated calcite was collected for $5 \mathrm{~min}$ in a pan as froth phase, and then dried in a drying furnace for $24 \mathrm{~h}$ at $55^{\circ} \mathrm{C}$.

Characterization of coated calcite was performed by TGA and TEM. TGA was performed by TGA 4000-ThermoGravimetric Analyzer (PERKIN ELMER). Nearly 5-10 mg of the sample were taken in the platinum pan and heated in $\mathrm{O}_{2}$ saturated atmosphere at a scanning rate of $10^{\circ} \mathrm{C} / \mathrm{min}$ up to $900^{\circ} \mathrm{C}$. TEM analysis was performed to investigate the morphology of the modified surface. It was carried out in a Jeol (JEM 2100) instrument at $200 \mathrm{kV}$ having a LaB6 filament with a point resolution of $0.194 \mathrm{~nm}$ and lattice resolution of $0.14 \mathrm{~nm}$.

\section{Results and discussion}

The effect of OA dosage on solid recovery in froth phase was investigated at $0,1,3.5,10$ and $25 \mathrm{~kg} / \mathrm{t} \mathrm{OA}$ (Figure 3). The recovery sharply increased with an increase in OA concentration up to $3.5 \mathrm{~kg} / \mathrm{t}$, at which $85.05 \%$ of marble dust was recovered in froth. Excess OA addition slightly improved the solid recovery. Highest recovery was obtained at $25 \mathrm{~kg} / \mathrm{t}$ of OA, which was around $99 \%$.

The surface characterization of coated calcite was investigated by TGA study and TEM images. The amount of alkyl mono/multilayer on the calcite surface was determined by TGA. In this method, the mass losses occurs by gradual increase in temperature indicating the decomposition of organophilic structure. The type of adsorption can also be investigated by TGA: initially, the free acid molecules are combusted at relatively lower temperature, indicating physical adsorption. Then, high-temperature mass losses occur showing the strong chemical adsorption on the filler surface.

TGA results obtained from the different amount of OA coated calcite were presented in Figure 4. The decomposition steps was observed clearly showing the existence of OA on calcite. Weight loss in the unmodified sample drew almost a linear path with the constant inclination up to $350^{\circ} \mathrm{C}$ 


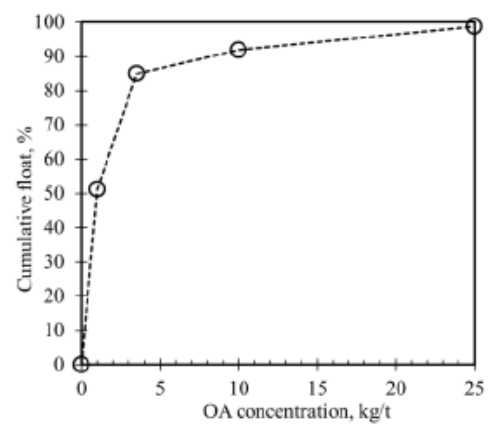

Fig. 3. Effect of OA dosage on the flotation of marble dust (Conditioning time: $8 \mathrm{~min}$, MIBC: $100 \mathrm{~g} / \mathrm{t}$ and stirring speed: $1300 \mathrm{rpm}$ ) Rys. 3. Wpływ dozowania OA na flotacje pyłu marmurowego (czas kondycjonowania 8 min, MIBC 100g/l i ilość obrotów 1300 obr/min

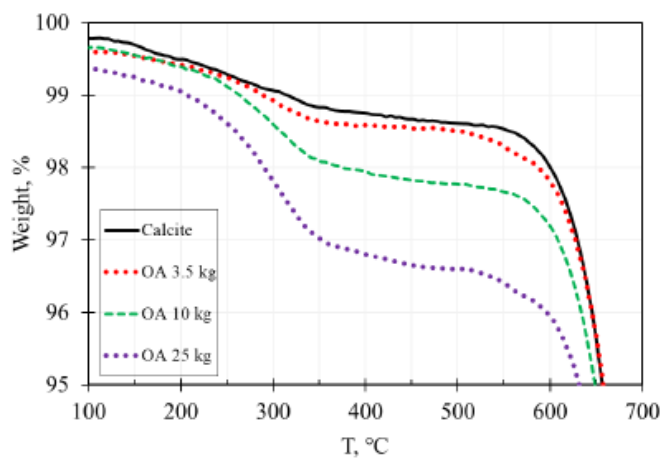

Fig. 4. TGA curve of (a) calcite, OA and OA-modified calcite with different amount acid Rys. 4. Krzywa TGA dal (a) kalcyt, OA I OA-modyfikowany kalcyt w różną ilością kwasu
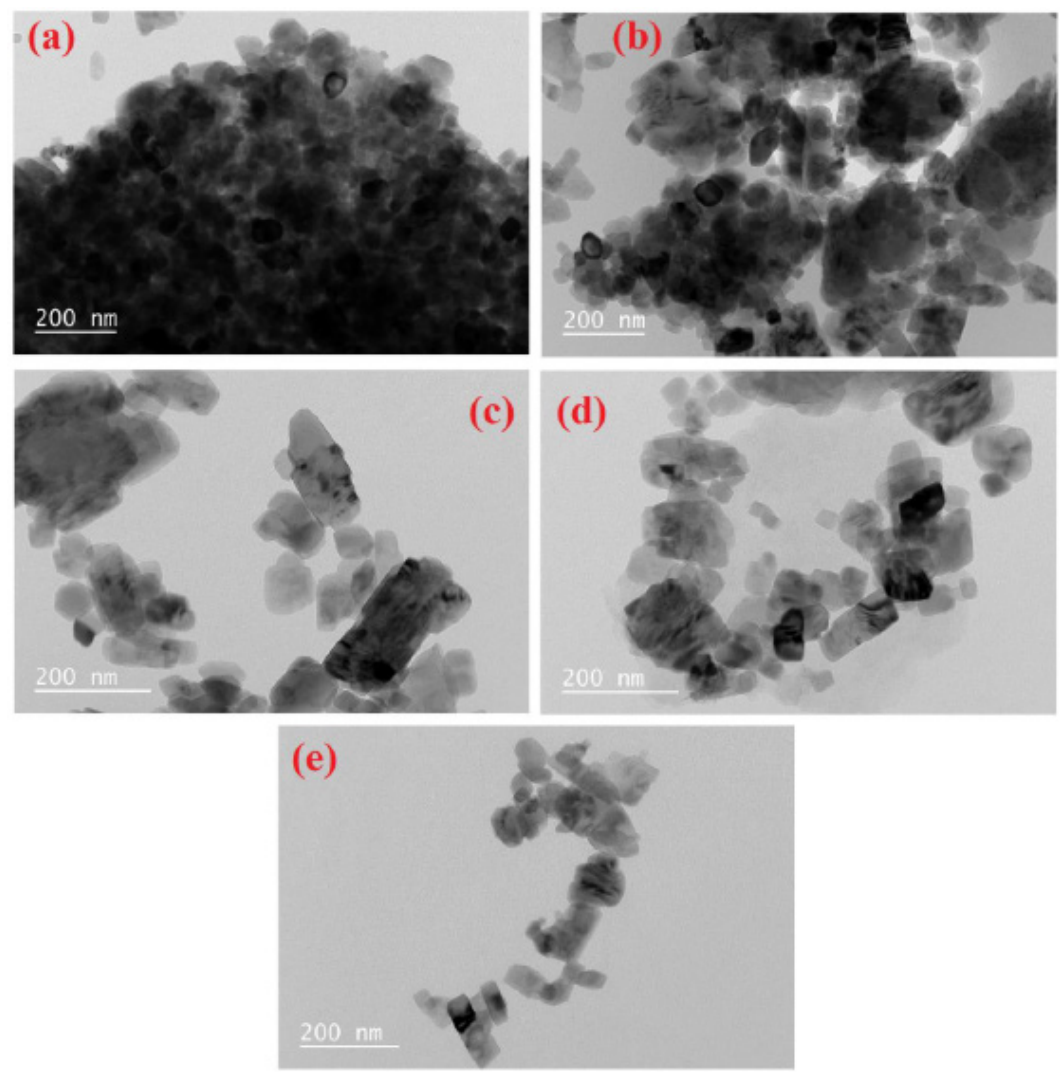

Fig. 5. The TEM images of unmodified and modified calcite particles with different amount of OA: [(a): Calcite test sample, (b): Calcite modified with $1 \mathrm{~kg} / \mathrm{t}$ of OA, (c): Calcite modified with $3.5 \mathrm{~kg} / \mathrm{t}$ of OA, (d): Calcite modified with $10 \mathrm{~kg} / \mathrm{t}$ of OA, (e): Calcite modified with $25 \mathrm{~kg} / \mathrm{t}$ of OA] Rys. 5. Obrazy TEM niemodyfikowanych i zmodyfikowanych ziaren kalcytu przy różnej ilości OA: ((a): próbka kalcytu, (b): kalcyt modyfikowany $1 \mathrm{~kg} / \mathrm{t} \mathrm{OA}$, (c): kalcyt modyfikowany 3,5 kg/t OA, (d): kalcyt zmodyfikowany $10 \mathrm{~kg} / \mathrm{t} \mathrm{OA}$, (e): kalcyt zmodyfikowany $25 \mathrm{~kg} / \mathrm{t} \mathrm{OA}$ ) 
indicating the removal of free water. Such a continues decrease in mass of sample up to reasonable high temperature was attributed to high active surface area of calcite powder. Agglomerated fine particles adsorbed free water molecules, which could hardly be removed due to capilarity property created in the agglomerated structure. On the other hand, remarkable change in the weight of modified marble dust could not be seen up to around $160^{\circ} \mathrm{C}$ except negligible decrease, which was attributed to the desorption of free water (Atta et al., 2016; Mihajlovic et al., 2009). Further heating the sample resulted in high rate of weight losses drawing parabolic path. The mass loss became more apparent at higher OA dosages. Obtained TGA curves indicated that OA species decomposed almost completely up to about $350^{\circ} \mathrm{C}$, above which weight loss continued almost negligible up to about $500^{\circ} \mathrm{C}$. At higher temperatures, calcination of marble dust occurred according to Reaction 1 drawing a sharp decrease in the weight loss especially above $600^{\circ} \mathrm{C}$.

$\mathrm{CaCO}_{3} \rightarrow \mathrm{CaO}+\mathrm{CO}_{2}$

Morphology of the calcite samples before and after modification with different amount of OA were characterized by using TEM (Figure 5). It is clear to see that unmodified calcite particles were agglomerated more compared to modified due to the high surface energy of hydrophilic surface. TEM images of unmodified particles present relatively darker particle distribution which complicate identifying a unique particle. As the OA dosage was increased, more transparent and independent particles were appeared due to less agglomeration.
This is attributed to the changing the hydrophilic calcite surface into hydrophobic (Deepika et al., 2013; Chen and Liu, 2006). The presence of the organophilic layer on the calcite surface can effectively prevent the agglomeration. In addition, the concentration of OA plays an significant role: higher OA consumption results in a more de-agglomerated particles. There is no remarkable change due to modification in shape and size/thickness of the coated particles compared to the uncoated, all presents cuboidal crystals.

\section{Conclusions}

Particle size distribution showed that fine GCC could be produced from slab cutting units, which is required for filler industry. Flotation method could be used to produce OA coated fine calcite powder. In general, the recovery increased with an increase in OA dosage but $10 \mathrm{~kg} / \mathrm{t}$ was found to be more beneficial. Characterization of modified calcite was performed by TGA and TEM. Two main weight loss steps were found by TGA study due to decomposition of OA and calcination of test sample. Another negligible one was also recorded at relatively lower temperatures, which was attributed to the desorption of free water. The mass loss became more apparent at higher $\mathrm{OA}$ dosages and continued almost negligible up to about $500^{\circ} \mathrm{C}$. Calcination occurred at higher temperatures, independent from surface modificaiton. TEM images were used for surface morphology. All calcite particles present a cuboidal crystal in shape. Aggregations have been detected in unmodified test sample, while the level of aggregation was found to be OA dosage dependent. 


\section{Literatura - References}

1. AHSAN, T., TAYLOR, D.A. The influence of surface energetics of calcium carbonate minerals on mineral-polymer interaction in polyolefin composites. The Journal of Adhesion, 1998, 67(1-4), pp.69-79.

2. ATTA, A.M., AL-LOHEDAN, H.A., EZZAT, A.O., AL-HUSSAIN, S.A. Characterization of superhydrophobic epoxy coatings embedded by modified calcium carbonate nanoparticles. Progress in Organic Coatings, 2016, 101, pp.577586.

3. CHEN, S., LIU, W. Oleic acid capped PbS nanoparticles: synthesis, characterization and tribological properties. Materials Chemistry and Physics, 2006, 98(1), pp.183-189.

4. DEEPIKA, S., HAIT, S.K., CHRISTOPHER, J., CHEN, Y., HODGSON, P., TULI, D.K. Preparation and evaluation of hydrophobically modified core shell calcium carbonate structure by different capping agents. Powder Technol, 2013, 235, pp.581-589.

5. FAN, H., WANG, X., LIU, J., XU, B. Surface modification of ground calcium carbonate with starch, sodium stearate, and hexametaphosphate. BioResources, 2015, 11(1), pp.957-964.

6. FEKETE, E., PUKÁNSZKY, B., TÓTH, A., BERTÓTI, I. Surface modification and characterization of particulate mineral fillers. Journal of Colloid and Interface Science, 1990, 135(1), pp.200-208.

7. MIHAJLOVIC, S., DAKOVIC, A., SEKULIC, Z., JOVANOVIC, V., VUCINIC, D. Influence of the modification method on the surface adsorption of stearic acid by natural calcite. J. Serb. Chem. Soc, 2009, 67, pp.1-19.

8. OSMAN, M.A., SUTER, U.W. Surface treatment of calcite with fatty acids: structure and properties of the organic monolayer. Chemistry of materials, 2002, 14(10), p.4408-4415.

9. SHEN, J., SONG, Z., QIAN, X., LIU, W. Modification of papermaking grade fillers: A brief review. BioResources, 2009, 4(3), p.1190-1209.

10. ZHANG, J., GUO, J., LI, T., LI, X. Chemical surface modification of calcium carbonate particles by maleic anhydride grafting polyethylene wax. International Journal of Green Nanotechnology: Physics and Chemistry, 2010, $1(2)$, p.65-71.

11. ZULLIG, J.J., MORSE, J.W. Interaction of organic acids with carbonate mineral surfaces in seawater and related solutions: I. Fatty acid adsorption. Geochimica et Cosmochimica Acta, 1988, 52(6), p.1667-1678.

\section{Charakterystyka powierzchni pytu marmurowego pokrytego kwasem oleinowym}

Kalcyt, będący najczęściej występującym minerałem w skorupie ziemskiej, ma szerokie obszary zastosowań, szczególnie w przemyśle polimerowym, jako mikronizowany funkcjonalny materiat wypetniający. Jest hydrofilowy w naturalnej postaci, a po modyfikacji powierzchni stat się hydrofobowy, aby spełnić wymagania przemysłu polimerów: niekompatybilność między wysokoenergetyczna hydrofilową powierzchnią kalcytu a niskoenergetyczną powierzchnią hydrofobowych polimerów jest poważnym problemem. Obróbka mikronizowanego kalcytu kwasami tłuszczowymi jest jedną z najczęstszych metod uzyskiwania modyfikowanej powierzchni mineralnej. W niniejszym badaniu do charakteryzowania powierzchni pyłu marmurowego pokrytego OA - kwasem oleinowym (OA), jako środek modyfikujący powierzchnię użyto kwasu tłuszczowego. Do badań wykorzystano drobne odpady z urządzenia do cięcia plyt $w$ zakładzie przeróbki marmuru. Próbkę poddano procesowi mokrej klasyfikacji w celu uzyskania mikronizowanej frakcji kalcytu do prac eksperymentalnych. Modyfikację powierzchni frakcji drobnej wielkości przeprowadzono w laboratoryjnej jednostce flotacyjnej. Jako do scharakteryzowana próbek zastosowano analizę termograwimetryczną (TGA) i transmisyjna mikroskopię elektronowa (TEM).

Słowa kluczowe: modyfikacja powierzchni, kwas olejowy, odpady marmurowe, mikronizowany kalcyt 
